\title{
Social representation of Alzheimer's disease for family caregivers: stressful and rewarding
}

\author{
Representação social da doença de Alzheimer para familiares \\ cuidadores: desgastante e gratificante \\ Representación social de la enfermedad de Alzheimer a \\ familiares cuidadores: desgastador y gratificante
}

Aline Duarte Folle ${ }^{1}$, Helena Eri Shimizu ${ }^{2}$, Janeth de Oliveira Silva Naves ${ }^{3}$

How to cite this article:

Folle AD, Shimizu HE, Naves JOS. Social representation of Alzheimer's disease for family caregivers: stressful and rewarding. Rev Esc Enferm USP. 2016;50(1):79-85. DOI: http://dx.doi.org/10.1590/S0080-623420160000100011

${ }^{1}$ University of California, Fielding School of Public Health, Los Angeles, CA, United States of America.

${ }^{2}$ Universidade de Brasília, Faculdade de Ciências da Saúde, Departamento de Saúde Coletiva, Brasília, DF, Brazil.

${ }^{3}$ Universidade de Brasília, Faculdade de Ciências da Saúde, Departamento de Farmácia, Brasília, DF, Brazil.

\begin{abstract}
Objective: To understand the content of Social Representation (SR) of family caregivers of Alzheimer's disease patients. Method: Interviews were conducted with 26 caregivers and analyzed by the ALCESTE software. Results: The SR content was structured in two thematic axes called Daily Life and Care and Medical and Emotional Concepts and Outcomes. The first axis creates images related to the routine of interaction with the sick person, and contains a description of care procedures, experiences, and practices applied every day. The second is composed of subjective and conceptual aspects that make up the social representation of Alzheimer's disease, with meanings related to the emotional, medical, and biological contexts. Conclusion: Due to the importance of topics related to patients' dependence and the personal and emotional consequences of the disease, overload is the main content of the SR of Alzheimer's disease for caregivers, and the understanding of these SR by health professionals should support the planning of interventions addressing this group of individuals.
\end{abstract}

DESCRIPTORS

Alzheimer Disease; Caregivers; Family; Qualitative Research. 


\section{INTRODUCTION}

In Brazil, the speed and particularities of demographic and epidemiological transition processes bring about a set of questions for managers and researchers of health systems that have consequences for society as a whole. Rapid population aging results in a higher incidence of diseases and more disabilities, and consequently in a potential increase in the use of health services ${ }^{(1)}$.

In the set of chronic noncommunicable diseases, the prevalence of dementia has increased with population aging and stands out as the source of disabilities and loss of functionality ${ }^{(2-3)}$.

The World Health Organization estimated that there were a total of 35.6 million people with dementia in 2010 and stated that this figure would double every 20 years $^{(4)}$. In Brazil, a survey carried out on the basis of a bibliographic review of prevalence studies estimated an incidence of 2.7 new cases of dementia in every 1,000 elderly people per year ${ }^{(5)}$.

The American Psychiatric Association, in the publication Diagnostic and Statistical Manual of Mental Disorders (DSM$5)^{(6)}$, lists the different stages and variations of dementia under the heading of neurocognitive diseases. Alzheimer's disease (AD) is the main cause of irreversible dementia in the world, and accounts for $60 \%$ to $70 \%$ of cases of progressive cognitive decline among elderly people. For this reason it is often considered synonymous with dementia. The typical clinical condition evolves to a progressive dependence for the performance of daily activities and to neuropsychiatric symptoms ${ }^{(7)}$. Treatment requires pharmacological and nonpharmacological interventions. The drugs currently available act in a symptomatic fashion, without the ability to change the underlying neuropathological conditions ${ }^{(7)}$.

In addition to patients, caregivers play an essential role in the process of dementia; they are responsible for the promotion of patients' general well-being, the administration of drugs, and the implementation of non-pharmacological treatment components. In Brazil, the relatives themselves usually take on care and are mostly wives and daughters ${ }^{(8)}$. Overload in the provision of care is a multidimensional response to stress generators associated with this activity, which depends on the characteristics of the disease and of the caregiver and may have a negative impact on the physical and mental health of the parties involved ${ }^{(9)}$.

The way in which relatives/caregivers deal with and understand Alzheimer's disease is of particular relevance, especially for Nursing and multiprofessional teams, due to the role these caregivers play in the therapeutic process and also because they have a greater risk of developing diseases and suffering from psychosocial losses. Moreover, the representations that relatives have of the disease may affect the way they provide care both positively and negatively. However, there are few studies that address the representations of Alzheimer's disease, especially from the perspective of relatives and caregivers.

In that context, we must remember that in the last 20 years Alzheimer's disease has taken hold of the scientific and medical communities and, consequently, appears as a new element to be redefined and made familiar. Therefore, it has become the object of a Social Representation of different social groups.

Thus, the objectives of this study are to understand the content of Social Representations of family caregivers of Alzheimer's patients about this disease, as well as their daily practices.

\section{METHOD}

As a methodological and theoretical starting point, the definition of Social Representation (SR) by Moscovici was adopted, as it is understood as a form of everyday knowledge, also known as common sense, that contributes to the establishment of a vision of reality that is common to a given social or cultural sphere, that is socially created and shared, and that has a practical approach to organization and domination of the environment and of guidance regarding conduct and communication ${ }^{(10)}$.

As to the formation process of SR, it occurs when a new object falls within social groups - for instance, a new scientific discovery - in which several mechanisms create and promote debates in its regard. Through anchoring and objectivization processes, new images and shared meanings arise, are directed to familiarization and communication within this environment, and are spread among these groups $^{(10)}$. Traditional media and, more recently, social and alternative media, act as important influential factors of creation and content of Social Representations concerning objectives of scientific and health fields ${ }^{(11)}$.

The present study was conducted in the Multidisciplinary Center for the Elderly at the Hospital Universitário de Brasilia (HUB), a reference center in the Federal District for the treatment of Alzheimer's disease and other dementias.

We included relatives aged over 18 who agreed to participate, who had cognitive and emotional abilities, and who were involved in care to some extent. The terms relative and caregiver were used as synonyms.

Twenty-six relatives/caregivers of Alzheimer's disease patients were interviewed. The invitation was sent sequentially and the choice of the number of interviewees was made when saturation of data was observed ${ }^{(12)}$.

An interview script was used, which addressed the following topics: perception of Alzheimer's disease; care provided; and factors that help and hinder care provided every day. At the end, sociodemographic and clinical data of the interviewees were collected, and doubts and questions were addressed at the same time. Interviews were conducted individually and in a private location. The interviewer introduced herself and explained the objectives and methods in simple language. The interviewer conducted all of the interviews, which lasted for approximately 50 minutes.

The interviews were transcribed in a single text block and the material was submitted to analysis of quantitative content by means of the ALCESTE software (Analysis of the co-occurring lexemes within the simple statements of a text). ALCESTE is considered to be a technique as well as a method of analysis of textual data by means of statistical procedures $^{(13)}$. The software performs an analysis in four steps. 
In the first step, it recognizes the Initial Context Units (ICUs) that correspond to each interview, and separates them into pieces of text of similar size, named Elementary Context Units (ECUs). In addition, it groups the occurrences of words according to their roots, by calculating the frequencies of these shortened forms.

In the next step, ECUs are classified on the basis of the similarity of the words that form them. This is done by means of a double-entry table that crosses the shortened forms (words) and ECUs with a hierarchical descending classification (HDC). The classification of the material is made based on the similarity of its content in the intraclass context and its dissimilarity in the interclass context.

In the third step, the program presents the Dendrogram of Hierarchical Descending Classification (HDC), which indicates the existing relationships between classes and provides elements that enable describing each class by its specific vocabulary (lexicon).

In the last step, on the basis of the ECUs chosen in each class, the software indicates those that stood out, thus enabling the contextualization of the most relevant vocabulary of classes.

In the context of SR studies, the objective of interpretation of results provided by the software is to understand the points of view that are commonly shared by a social group at a given point in time ${ }^{(13)}$. Therefore, the result of the co-occurrence analysis was used for qualitative interpretation and, supported by hermeneutics, empirical data were understood and interpreted in the light of Social Representations Theory.

The research project was approved by the Research Ethics Committee of the Faculdade de Ciências da Saúde of the Universidade de Brasília, under number 008/10. All participants signed a Free and Informed Consent Form and were guaranteed freedom to participate and confidentiality of data. Relatives/caregivers were identified by codes composed of the letter "I" (Interviewee) and numbers from 1 to 26.

\section{RESULTS}

The profiles of the interviewees are found in Table 1. It should be noted that relatives/caregivers were predominantly women $(n=20)$, generally sons/daughters, aged over 41 years old. The group average schooling was 7.2 years.

Table 1 - Description of sociodemographic characteristics of caregivers interviewed, Multidisciplinary Center for the Elderly Brasília, DF, Brazil, 2012.

\begin{tabular}{llc}
\hline Characteristic & Category & N \\
\hline \multirow{2}{*}{ Gender } & Female & 21 \\
& Male & 5 \\
\multirow{3}{*}{ Age } & 20 to 40 years & 3 \\
& 41 to 60 years & 15 \\
& Over 60 years & 8 \\
Schooling & No schooling & 1 \\
& 1 to 4 years & 5 \\
& 5 to 8 years & 2 \\
& 9 to 11 years & 8 \\
& More than 11 years & 10 \\
\hline
\end{tabular}

continued...

\begin{tabular}{llc}
...Continuation & & \\
\hline Characteristic & Category & N \\
\hline \multirow{3}{*}{ Income $^{1}$} & 1 to 4 times the minimum wage & 10 \\
& 5 to 10 times the minimum wage & 6 \\
& More than 10 times the minimum & 10 \\
& wage & 8 \\
& Spouse & 15 \\
\multirow{3}{*}{ Kinship } & Son/daughter & 1 \\
& Sister & 1 \\
& Granddaughter & 1 \\
\multirow{3}{*}{ Workload } & Daughter-in-law & 14 \\
& Full time & 12 \\
\hline
\end{tabular}

1 The amount of the minimum wage at the time of the study ranged between $\mathrm{R} \$ 510.00$ and $\mathrm{R} \$ 545.00$, Brazil, 2012.

\section{ALCESTE RESULTS}

From the total corpus of transcribed interviews during the HDC, 610 ECUs were taken into account for analysis, out of the 860 initial ones, which corresponds to $71 \%$ and is considered as good ${ }^{(13)}$. The analysis resulted in five stable classes grouped into two thematic axes, with a minimum number of 44 ECUs for the definition of a class.

The dendrogram (Figure 1), which is a graphic representation of grouping of the most relevant and correlated contents resulting from the HDC, shows classes 1 and 5 grouped into a thematic axis named Daily Life and Care and classes 2, 3, and 4 into another axis named Medical and Emotional Concepts and Outcomes.

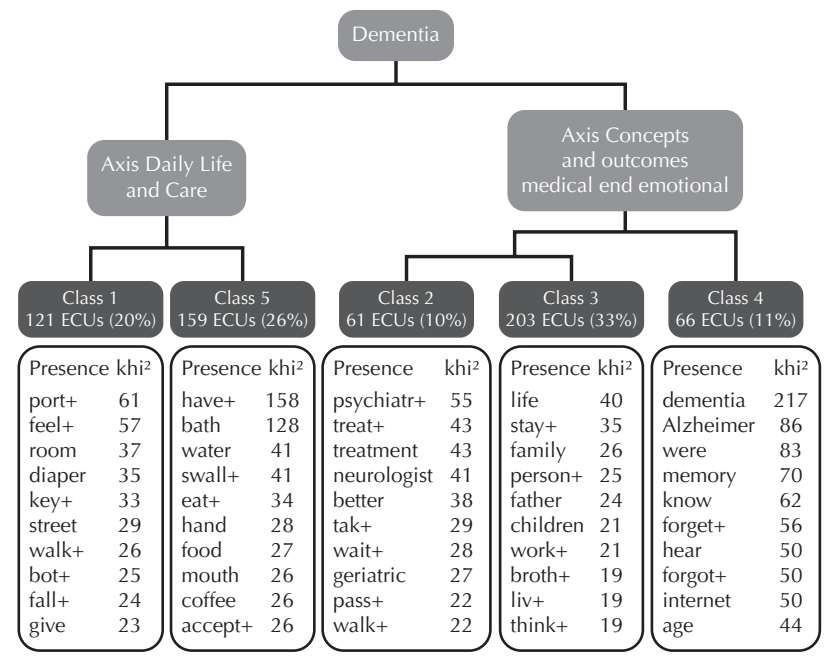

Figure 1 - Dendrogram resulting from the Hierarchical Descending Classification: graphic representation of grouping of the most relevant content, Multidisciplinary Center for the Elderly Brasília, DF, Brazil, 2012.

\section{Daily Life ANd CARe AXIS}

This axis presents images related to everyday care activities. Contexts shown are related to the routine of interaction with the sick person, with the description of care procedures, and of experiences and practices applied every day.

Class 1 contains in its lexicon many verbs that express practical and daily actions of care that deal mainly with 
difficulties related to behavior manifestations. The semantic content to which words are related refers to the description of examples of situations caused by these manifestations and to actions and practices routinely used to provide care to individuals who present several behavior changes, as seen here:

Then, she gets out (of the shower), dries and so, then she sits on the bed and we call her: Let's put the diaper. It's me and my daughter who put the diaper. Then we dress her and she sits right away. Sometimes she gets upset, lies down, I struggle and struggle, then I quit. Shortly after, I come back and she's already sitting or has already stood up. It looks like it's on purpose (I-12).

In class 5 the matter of dependence for basic daily activities is clear, expressed through examples of how and which activities were performed by caregivers.

It's very exhausting. Because it starts in the morning with bygiene, taking her to the bathroom to wash her face, brush her teeth, comb her hair, wash hands, have breakfast (I-14).

It should be noted that the distress of Alzheimer's patients' caregivers is also seen in detail, due to the need to take on basic care duties throughout the day and on a daily basis. The sequence of care activities shows that there are very few opportunities to stop or rest.

\section{Medical and Emotional Concepts and Outcomes axis}

This axis is composed of subjective and conceptual aspects that make up the social representation of Alzheimer's disease, with meanings related to the emotional, medical, and biological contexts.

Class 2 has as specific terminology the names of the medical fields, which very often describe the therapeutic route for obtaining a diagnosis and a care plan. Usually, relatives are the first to notice something different with the patient, and this perception triggers a journey through different medical services in the search for explanations about the situation.

Always at the end of the afternoon he would say: "I want to go home." And then we found it strange because he wasn't recognizing the environment where he was living. Then he wasn't recognizing his children anymore. And we took him to a psychiatrist. It was when he took all those tests, scans and so (...). (I-8).

In the content of this class, the expectations regarding the prognosis are also shown. All the hope placed in the medication, so as to have the situation solved or controlled, is also expressed.

No, I waited for an improvement, you know? Because I had great faith. Because it was at the beginning, you know, when you go see the doctor at the beginning, there is greater chance, not of cure, because we know there is not, but at least to make it stable. Even if it develops, but let it be slower (I-11).

Class 3 is the one that was structured with the highest percentage of ECUs, that is, the one that gave more sense to speeches and to the studied representation. The specific terminology and content of classes are related to the personal and family aspects, in addition to emotions associated with the experience of the disease. Here the impact on personal life and family dynamics is observed, as well as the description of emotions and feelings related, in addition to the fact that speculations regarding the causes of the disease are related to family and emotional conflicts.

I had to change my life. I went through a terrible crisis. Then I had depression and became like this. (...) My husband was very patient, you know? And my children, despite their young age, they kept talking to me. I also searched for help with people who have problems, because families have, right? Then, why? Because your life stops. You know? You stop. God, what will be done with me now? Alone (I-11).

Although the great negative emotional charge is strongly present in this class, a positive emotional content is also observed and is related to personal satisfaction and solidarity. The examples below present speeches with a high emotional charge regarding the motivations to take over care.

(...) you scratch my back and I'll scratch yours. So when she was in good health, she helped me, you know? Now it's my turn to give back and contribute to all this. We don't do this as an obligation, but for the love of the person. And she is also my daughters' mother. And I have to be grateful to her for having belped me (I-3).

The role of providing care is reported as dignifying, and it is explained by affection and commitment to care for others. Empathy seems to be the feeling that shapes this caregiver-caregiving relationship and makes it more enjoyable.

Then it strengthens the bonds. (...) I feel love, I feel warmth, and I feel sorry in the sense that it hurts to see a person who always worked so hard and is now in the hands of other people, so dependent. I know she suffers, I think it must be very sad to feel this pain she feels and there is nothing I can do for her, or she for herself, and this is crazy (I-6).

In this class the efforts made by caregivers to understand the causes of the disease are also seen. There are several explanations, heredity, life habits, and psychological stress being the most relevant.

Also because of all she went through (...) So we more or less figure it out. Because it was after her father's death that she got like this, that she got worse (I-4).

But I think it has to do with life habits, heredity, attitudes people have; some are more introspective, others are more outgoing (I-9).

In class 3, we see semantic components related to the loss of the ability to keep in touch with reality, which is experienced in a very painful manner by relatives, as it often comes associated with a feeling of death for the Alzheimer's patient.

Because this is death somehow. The person is dying. Their memory is already dead (I-20).

In this process, which also refers to the person's loss of identity, the exchange of roles within the family often occurs, resulting in great angst and anxiety.

(...) How come you cannot eat? Because I always saw my mother as that person who hit me when I was a child, because I messed around a lot, and that active person used to be a teacher. So this change was very difficult (I-23). 
Class 4 has as specific content words that name, define, and explain the clinical picture. In that sense, in speeches related to this class, the concepts of the disease are introduced with terms from biomedical and popular universes and they also include possible causes, examples of clinical manifestations, and means of research adopted. They compose the SR of Alzheimer's disease.

As far I know, Alzheimer's is like a cognitive deficit, which generally affects elderly people. There is a loss of several cognitive properties, and also of their psychomotor skills. Sometimes we really have to stop to remember that they are not doing that because they want to, because we tend to forget this, and that they don't understand that we asked them to do something because they really need help, and we have to understand that (I-1).

Regarding the sources of information used, the words "Internet" and "research" are relevant and correlated in ECUs of this class, which indicates that these means of communication are the main vehicles to disseminate the SR of Alzheimer's, as explained below:

I try to read about Alzheimer's since she's had this problem, since it has been found. And I also read on the Internet information about Alzheimer's (I-26).

In content associated with this class, we finally highlight the presence of the term mal de Alzheimer, in Portuguese, in the list of distinctive words $\left(\mathrm{X}^{2}=10\right)$. This term reflects an inadequate translation of the French medical literature ( $m a l-$ adie $=$ disease $)$, which was included as a matter of common sense to explain some diseases. In fact, this kind of interpretation contributes to a negative representation of the disease.

\section{DISCUSSION}

Regarding the profile of family caregivers, it was observed that most caregivers are women, generally daughters, which confirms other studies carried out in $\mathrm{Brazil}^{(8)}$. The group also had a good education level. Thus, we should assume that these are people who have a greater possibility of access to information and to the language of reified universes.

Historically, women take over the care of others in particular life events. In the context of unequal gender relationships ${ }^{(8,14)}$, taking care of an ill relative implies a solidarity relationship and abnegation, attributed to women as a natural role and imposed as a social obligation, whereas it is attributed to men as an inadequate role.

Thanks to daily experiences, caregivers gain knowledge to deal with difficulties resulting from dependence and behavior manifestations that arise in patients with Alzheimer's and other dementias. This is a process permeated by feelings of strangeness in regard to the new condition. Then the practical matter associated with the disease is developed, which commonly occurs as a result of patients' dependence on care ${ }^{(15-16)}$.

The daily care of people with dementia causes intense physical wear, in addition to causing strong feelings, sometimes dubious, that result in emotional wear. Overload resulting from the role of the caregiver, sometimes the only one, and from the adverse behavior of the person who is being cared for, are potential stress factors. Loss of patience may occur in caregivers' routine when they cannot stand the pressure and the permanent stand-by state, but since this is not socially accepted, it results in a strong feeling of guilt ${ }^{(8)}$.

The negative or positive emotional charge associated with care may be related to factors such as: patients' clinical characteristics; psychosocial and socioeconomic characteristics of the family; the reasons why relatives take over care; and the characteristics of care work division ${ }^{(15-16)}$. In that sense, it has been observed that the positive aspect associated with caregivers' well-being is inversely related to overload in the provision of care ${ }^{(9)}$.

The loss of memory of Alzheimer's patients is painful for the family, who can associate it with the loss of their relative. A study about the loss of personal and social identity in Alzheimer's disease discussed the process that results in cognitive, emotional, physical, and social deterioration in such a way that the Alzheimer's patient's present time begins to be constructed and interpreted socially according to the disease, in a kind of relationship in which dehumanization and signs of social death prevail ${ }^{(14)}$.

In this universe, changes in the domestic environment can have actual consequences on the caregivers' health. In this way, Alzheimer's, as well as other diseases that have a great psychosocial impact, are considered to be family diseases ${ }^{(17-18)}$.

In this study, it was evident that many caregivers stop living their own lives to devote themselves to the ill person who suddenly needs help in nearly all activities. Abnegation appears to be a significant consequence of care, and it affects personal, professional, and social lives. Negative consequences, such as caregivers' isolation, are shown in other studies ${ }^{(8,14,17)}$.

Social support structures remain fragile in Brazil and do not take the form of an organized support network, making evident the lack of social policies that provide support to families who care for fragile and dependent people such as Alzheimer's patients.

However, in this study, care is also seen by caregivers as rewarding, especially as a form of repayment for care received at another point in time. This is a key factor for commitment, either in the present or in the near future.

In this context, caregivers are encouraged to position themselves with regard to the disease that they have to deal with and try to make this strange element familiar, as explained in a study on the formation of $\mathrm{SR}^{(19)}$. Generally speaking, relationships between medical knowledge and common sense occur in two ways, with an exchange of knowledge and influence between both worlds.

In the SR of the group studied, Alzheimer's disease is understood as an incurable disease, supported by the explanations of the medical community, but hope for a more clement prognosis, or sometimes for cure, remains alive and is often based on religious faith.

Alzheimer's disease and other dementias have become increasingly present in the biomedical environment, and this phenomenon is called the biomedicalization of Alzheimer's disease. The representation of this illness as a chronic disease of neurological origin seems to contribute to educate patients and their families, bringing them into a medicalized context, which can be interpreted as less threatening than a condition that is unknown in the medical environment ${ }^{(20)}$. 
This integration of medical explanations for changes perceived in patients is one of the ways to become familiar with the unfamiliar, and can, on the one hand, bring psychological relief and mitigate feelings of guilt and shame of the family, but on the other hand can also be a source of stigma.

In the academic world, the use of the term Alzheimer's disease is recommended. However, the other term used in Brazil (mal de Alzheimer) was often used by relatives and it is also reinforced by media, which contributes to the construction and dissemination of negative stereotypes associated with the disease. This process ends up, as discussed above, in stigmatization and emotional overload of the family.

The media is mainly interested in the fact that Alzheimer's disease is still considered incurable from a medical point of view. Thus, new scientific discoveries in the disease, especially those related to potential new treatments and to cure, are constantly in evidence and foster debate within society ${ }^{(11)}$.

As part of the effort to humanize the health practices of an Alzheimer's patient, professionals must remember that relatives acquire knowledge and practice on a daily basis, and this is as legitimate as scientific knowledge. The content discussed herein has limitations resulting from the fact that it involved only the standpoint of care provision and knowledge exchanged with patients during the routine of clinical practice. However, it should be valued and used to understand the context of meanings in which the disease is experienced and to plan and intervene with effective approaches and languages, and with less interference by stigmas. This discussion must be deepened and updated in order to allow for a wider understanding of Alzheimer's disease and care in the context of new configurations of family within modern society and the integration of this knowledge for a better quality of life of the parties involved.

It was observed that the social representation of Alzheimer's disease is composed of content related to patients' dependence, and the personal and emotional consequences of the disease for relatives. As a consequence, care and disease are represented by relatives as sources of physical and emotional overload, and they are either imminent or ongoing. However, they are also represented as sources of dignifying feelings, which favor feelings of pleasure in this relationship of care.

The semantic fields of words contained in shared content show that, for this social group, Alzheimer's is widely regarded as a disease that is based on the explanations of biomedicine. However, a close look reveals that this disease goes far beyond the medical and scientific fields.

\section{CONCLUSION}

From a comprehensive care point of view, and given the essential role of relatives/caregivers in the process of dementias and their vulnerable position regarding health risks, we suggest that these caregivers be given special attention by health services. Educational interventions and emotional and social support are associated with a decrease in overload and in the improvement of quality of life of caregivers. The health system will have to adapt in order to meet the growing, distinctive demand of patients with chronic diseases such as dementias, and support management policies and care strategies that allow for improving services and providing multidisciplinary approaches that include psychosocial aspects in therapeutic levels.

\section{RESUMO}

Objetivo: Conhecer o conteúdo da Representação Social (RS) dos familiares cuidadores de pacientes com doença de Alzheimer sobre a doença. Método: Foram realizadas entrevistas com 26 cuidadores, analisadas pelo programa ALCESTE. Resultados: O conteúdo da RS estruturou-se em dois eixos temáticos denominados Cotidiano e Cuidado e Conceitos e Repercussões Médicas e Emocionais. O primeiro eixo traz campos de imagens relacionadas à rotina do convívio com o familiar doente, contendo a descrição dos rituais do cuidado, as manifestações vivenciadas e as práticas utilizadas no cotidiano. O segundo é composto por aspectos subjetivos e conceituais que compõem a representação social da doença de Alzheimer, com significados relacionados ao contexto emocional, médico e biológico. Conclusão: Devido à importância dos temas relacionados à dependência do paciente e às repercussões pessoais e emocionais da doença, a sobrecarga é o principal conteúdo da RS da doença de Alzheimer para os cuidadores e o conhecimento dessas $\mathrm{RS}$ pelos profissionais de saúde deve subsidiar o planejamento de intervenções voltadas a esse grupo.

\section{DESCRITORES}

Doença de Alzheimer; Cuidadores; Família; Pesquisa Qualitativa.

\section{RESUMEN}

Objetivo: Conocer el contenido de la Representación Social (RS) de los familiares cuidadores de pacientes con enfermedad de Alzheimer acerca de la enfermedad. Método: Se llevaron a cabo entrevistas con 26 cuidadores, analizadas por el programa ALCESTE. Resultados: E1 contenido de la RS se estructuró en dos ejes temáticos denominados Cotidiano y Cuidado y Conceptos y Repercusiones Médicas y Emocionales. El primer eje trae campos de imágenes relacionadas con la rutina del convivio con el familiar enfermo, conteniendo la descripción de los rituales del cuidado, las manifestaciones vividas y las prácticas utilizadas en el cotidiano. El segundo está compuesto de aspectos subjetivos y conceptuales que componen la representación social de la enfermedad de Alzheimer, con significados relacionados con el contexto emocional, médico y biológico. Conclusión: En virtud de la importancia de los temas relacionados con la dependencia del paciente y las repercusiones personales y emocionales de la enfermedad, la sobrecarga es el principal contenido de la enfermedad de Alzheimer para los cuidadores y el conocimiento de dichas RS por los profesionales sanitarios debe subsidiar la planificación de intervenciones dirigidas a ese grupo.

\section{DESCRIPTORES}

Enfermidad de Alzheimer; Cuidadores; Familia; Pesquisa Cualitativa. 


\section{REFERENCES}

1. Küchemann BA. Envelhecimento populacional, cuidado e cidadania: velhos dilemas e novos desafios. Soc Estado. 2012;27(1):165-80.

2. Santos MD, Borges SM. Percepção da funcionalidade nas fases leve e moderada da doença de Alzheimer: visão do paciente e seu cuidador. Rev Bras Geriatr Gerontol. 2015;18(2):339-49.

3. Gutierrez BAO, Silva HS, Guimarães S, Campino AC. Impacto econômico da doença de Alzheimer no Brasil: é possível melhorar a assistência e reduzir custos? Ciênc Saúde Coletiva. 2014;19(11):4479-86.

4. World Health Organization; Alzheimer's Disease International. Dementia: a public health priority. Geneva: WHO; 2012.

5. Burlá C, Camarano AA, Kanso S, Fernandes D, Nunes R. Panorama prospectivo das demências no Brasil: um enfoque demográfico. Ciênc Saúde Coletiva. 2013;18(10): 2949-56.

6. American Psychiatric Association. Diagnostic and Statistical Manual of mental disorders: DSM-5. 5th ed. Arlington: APA; 2013.

7. Grand JHG, Caspar S, MacDonald SWS. Clinical features and multidisciplinary approaches to dementia care. J Multidiscip Healthc. 2011;4:125-47.

8. Oliveira AP, Caldana RHL. As repercussões do cuidado na vida do cuidador familiar do idoso com doença de Alzheimer. Saúde Soc. 2012;21(3):675-85.

9. Gonçalves-Pereira M, Carmo I, Silva JA, Papoila AL, Mateos R, Zarit SH. Caregiving experiences and knowledge about dementia in Portuguese clinical outpatient settings. Internat Psychogeriat. 2010;22(2):270-80.

10. Moscovici S. Representações sociais: investigações em psicologia social. $7^{\text {a }}$ ed. Petrópolis: Vozes; 2010. O fenômeno das representações sociais; p. 29-109.

11. Vasconcellos-Silva PR, Castiel LD, Griep RH. The media-driven risk society, the anti-vaccination movement and risk of autismo. Ciênc Saúde Coletiva. 2015;20(2):607-16.

12. Fontanella BJB, Luchesi BM, Saidel MGB, Ricas J, Turato ER, Melo DG. Amostragem em pesquisas qualitativas: proposta de procedimentos para constatar saturação teórica. Cad Saúde Pública. 2011;27(2):388-94.

13. Camargo BV. Alceste: um programa informático de análise quantitativa de dados textuais. In: Moreira A. Perspectivas teórico-metodológicas em representações sociais. João Pessoa: UFPB; 2008. p. 511-39.

14. Martorell-Poveda MA, Reverol CLP, Montes-Muñoz MJ, Jimenez-Herrera MF, Burjalés-Marti MD. Alzheimer: sentidos, significados y cuidados desde una perspectiva transcultural. Index Enferm. 2010;19(2-3):106-10.

15. Berry B, Apesoa-Varano EC, Gomez Y. How family members manage risk around functional decline: the autonomy management process in households facing dementia. Soc Sci Med. 2015;130:107-14.

16. Rapp T. Patients' diagnosis decisions in Alzheimer's disease: the influence of family factors. Soc Sci Med. 2014;118:9-16.

17. Cerquera Córdoba AM, Granados Latorre FJ, Buitrago Mariño AM. Sobrecarga en cuidadores de pacientes con demencia tipo Alzheimer. Psychol Av Discip. 2012;6(1):35-45.

18. Carpentier N, Ducharme FC, Kergoat MJ, Bergman H. Social representations of barriers to care early in the cares of caregivers of persons with Alzheimer's disease. Res Aging. 2008;30(3):334-57.

19. Torres EC. Representações das demências na imprensa (2001-2010). Sociol Probl Prat. 2013;(73):9-33.

20. Seima MD, Lenardt MH, Caldas CP. Relação no cuidado entre o cuidador familiar e o idoso com Alzheimer. Rev Bras Enferm. 2014;67(2):233-40. 